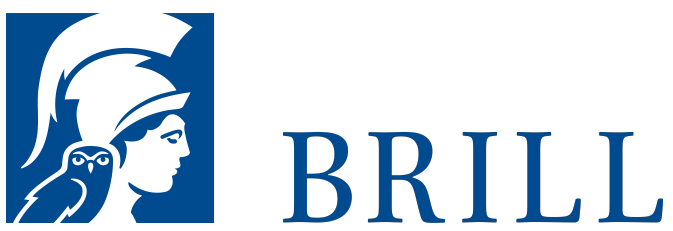

\title{
Metropolitan Maternity
}

Maternal and Infant Welfare Services in Early Twentieth Century London

Author: Lara V. Marks

For centuries London has been at the centre of the social and economic fabric of British life, and its empire. London has not only been renowned for its pivotal role in the world of finance and politics, but also for its acute problems of overcrowding and social and economic dislocation. Starting in 1902 and ending just before the outbreak of the Second World War, Metropolitan Maternity highlights the distinct role London played in these years within the debates and policies concerning the economic and military future and physical welfare of the nation. Focusing on the expansion of maternal and child health and welfare services in the early twentieth century, this book shows that London mothers and children tended to be better served than those in provincial cities or rural areas. Yet even in London some areas were better served than others. A central theme of the book is the complexity of socio-economic and political forces that determined the differing levels of provision and health standards within the city. The book also examines the increasing emphasis placed on state sponsorship of health services in the early twentieth century and the growing willingness to involve and listen to mothers and their needs in the planning and development of services.

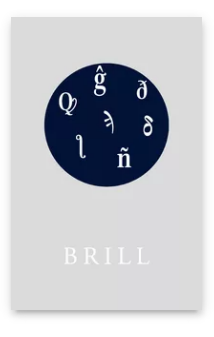

Pages: xxii, 344 pp.

Language:

English

Subjects:

History of

Medicine,

History, General, Social Sciences

Publisher: Brill

Series:

Clio Medica

Online, Volume: 36

Clio Medica,

Volume: 36

E-Book (PDF)

Released online:

29 Jan 2020

ISBN: 978-90-

04-41845-5

List price

USD ÂA $\$ 195.00$

Hardback

Publication date:

o1 Jan 1996

ISBN: 978-90-

5183-901-2

List price

USD ÂA $\$ 184.00$

Paperback 
ISBN: $978-90-$

5183-913-5

Order information: Order online at brill.com +44330 3330049 | customerservices@brill.com Submission information: brill.com/authors

Titles published by Brill | Fink, Brill | mentis or Brill | Schöningh: +49(o)71 5413279216 | brill@brocom.de 